\title{
Graduation is the Hallmark of Excellence-How Colleges Can Achieve High Rates
}

\author{
Ruben Gentry \\ Jackson State University, Jackson, Mississippi, USA
}

\begin{abstract}
Fine facilities, adequate financial aid, and sufficient resources are crucial elements for a university to be successful. But unless students graduate at an appropriate rate, the university will ultimately be considered ineffective. Students who exit the university without a degree will have their dreams deferred and often struggle to lead a life of any quality. Among those who fail to graduate are a disproportionate number of African Americans and other minorities; this of which must change for a country to thrive and be respected as an exemplary democracy. However, those who do graduate are prepared and financially compensated to lead and make a positive impact in education, politics, science and technology, and human-service areas. This manuscript provides findings from a thorough review of literature on graduation issues and concerns to support development of a framework of tenets to increase graduation rates, especially for African Americans. Further, it highlights specific efforts of a particular college to enhance its graduation rates and provides implications for future directions.
\end{abstract}

Keywords: African Americans, graduation rates, higher education, instructional strategies

\section{Introduction}

The urgency for high graduation rates will continually be upon colleges and universities because well qualified graduates are increasingly needed in society (Snyder, 2013). Technology is swiftly changing the place of work; it diminishes the demand for traditional training and places more value on problem-solving and communication expertise. Estimation is that by 2018 about 62 percent of U.S. jobs will require preparation beyond high school and bachelor's degree holders will earn up to 74 percent more than those without a high school diploma (Rothman, 2012).

Of the students who graduate high school in the United States only 40 percent continue to acquire a college degree, with the percentage for African Americans being considerably lower. Students who are unsuccessful at earning a degree are often unprepared for the rigor of college work, lack the fortitude to persist, pass up opportunities to ask professors for help, and fail to establish peer support groups. The impact of these factors and behaviors make the country rank 15th in the world in college completion (Mulrine, 2010; Rothman, 2012). However, it has been found that students who do succeed in college often put forth extensive effort, display a disposition to succeed, and are well prepared for college work (Martin \& Dahmen, 2009).

As universities endeavor to produce more graduates, they must be careful to not advance a completion-only paradigm at the expense of quality learning; they must develop and implement programs that lead to excellence for all. Educational practices and policies are needed to significantly increase the number of 
students who graduate in a timely manner and are well prepared for the challenges of work and life. This will raise the intellectual capital needed to build a strong economy and democratic society (Humphreys, 2012). This manuscript thoroughly investigated graduation issues and concerns in order to establish a framework of tenets to increase graduation rates. It further illustrated one college's efforts to enhance its graduation rates and provided implications for future directions.

\section{Literature Review}

The review of literature focused on the need for higher education, problems and issues with graduation rates, and teaching strategies that promote graduation. This helped to set the stage for developing promising tenets to increase college graduation rates.

\section{Need for Higher Education}

There is a need for more than a high school diploma to succeed in society; people need problem-solving and communication expertise that is developed at the college level. The Obama administration's "Blueprint for Reform" proposed that all students who graduate high school should be ready for college and/or a career" (Mulrine, 2010; Rothman, 2012). The graduation rate for minorities, particularly African Americans, is of great concern. Minority students are often of low socioeconomic status, earn lower test scores, delay enrollment in college, attend community colleges, take developmental courses, and become parents earlier; all of these conditions and behaviors of which have negative impact on graduating from college (Nemko, 2008; Paskus, 2011; Sibulkin \& Butler, 2005; Townes, 2007).

A well-educated citizenry is needed to excel globally. This is more likely to be accomplished with affordable access to higher education and adequate provisions for earning a college degree or certification (Snyder, 2013).

\section{Problems and Issues With Graduation Rates}

Concerns about graduation rates in college are predated by the same concerns in high school. While there has been some increase in high school graduation rates, far too many students still fail to receive a meaningful education and a high school diploma. At the beginning of the 21st century approximately two-thirds of U.S. public school students graduated high school with a regular diploma; but the Editorial Projects in Education Research Center showed that the graduation rate rose to about $75 \%$ for the class of 2010 . There were improvements for historically underserved populations and some closing of the graduation gaps between whites and Latinos and Black peers (Swanson \& Lloyd, 2013).

Students of parents who did not attend college constitute around $27 \%$ of all students who graduate high school. These students are often Hispanic or African-American, female, older, come from lower-income families, and have more financial dependents than other students. All of these conditions and factors are associated with low graduation rates. However, many of these students possess an embedded desire to attend college and they see themselves as very capable of completing college work (Gibbons \& Shoffner, 2004). While getting accepted in college can be challenging for students with substandard preparation, it helps when they determine their unique assets and then seek a college that is looking for someone with those capabilities. Other strategies that may help students in getting accepted in college are: get involved in extracurricular activities; take honor classes and rigorous courses; engage in internships, and come to believe that they can achieve (Charski, 2007). 
The cost and challenges associated with attending college can be prohibitive. According to Khan (2013), between 2000-2001 and 2010-2011 the cost for undergraduate tuition, room, and board at public institutions rose $42 \%$. This makes it necessary for many students to seek financial aid. Still many students must enroll in large classes and at the same time assume family responsibilities such as caring for children or elderly parents (Snyder, 2013).

Major factors that are essential to college success lie within students. Those who succeed tend to possess a deep desire and disposition to succeed, work hard at their studies, and are prepared for college work (Martin \& Dahmen, 2009). To excel students also need good writing skills, reading ability to comprehend complex texts, and basic mathematical skills (Rothman, 2012). Interaction with peers and faculty may positively influence college persistence (Oseguera \& Rhee, 2009). One study strongly supported the contention that good high school preparation, temperament to succeed, and extensive effort during the freshman year are key factors for college graduation (Monto \& Dahmen, 2009).

Graduation rates have been a particular challenge for Historically Black Colleges and Universities (HBCUs). Though HBCUs constitute a meager three percent of American higher education institutions and yet manage to graduate some 24 percent of all black college students, many of the students come from low-income families and are at risk of dropping out. The students who beat the odds and remain at HBCUs generally receive a very scholarly experience, even with limited financial resources and lower rankings compared with white campuses (Cole, 2007). A principal fault in most college rankings is their measure of how prestigious institutions are rather than how effectively they prepare students. However, the Washington Monthly rates colleges on their performance with the students they have, regardless of the students' backgrounds or SAT scores, on factors that measure the national goals of increasing social mobility, producing research, and inspiring public service (Fishman \& Kelchen, 2012). In 2011 the HBCU Tuskegee University was first in Washington Monthly rankings of baccalaureate colleges. Sixty-seven percent of its students received Pell Grants and it yet had a graduation rate seven percentage points higher than predicted (Dillon, 2011).

There is a positive correlation between higher education and higher salaries (Gibbons \& Shoffner, 2004). Due to the shortage of college graduates, salary for those with bachelor's degrees is much more than for those with high school diplomas. If current trends continue, college graduates will earn twice as much as high school graduates by 2025 (Hoover, 2005; Rothman, 2012; Sibulkin \& Butler, 2005).

\section{Teaching that Promotes Graduation}

College graduates need appropriate skills and knowledge to gain employment in higher paying positions. Students who are able to appropriately manage their time and develop proper study habits are generally motivated and situated to earn a college degree (Snyder, 2013).

Capitalizing on available academic and nonacademic data, school leaders are developing strategies to increase the number of high school students who earn diplomas. They monitor students' performance and identify potential dropouts before they leave school. With an emphasis on graduating students prepared for college and careers, school districts are paying attention to how they deliver instruction and common things such as how students get to school. Some of the data collected and used include grade level, grade point average, and number of suspensions and absences for students who are at risk of leaving school. The objective is to intervene with those most likely to drop out (Aarons \& Sawchuk, 2010). Some school districts use graduation coaches to work with at-risk students. The coaches identify students who need extra support and 
assist them in finding ways to pass their courses and graduate (Zehr, 2010).

One study found that students learned twice as much in classes that used interactive approaches rather than the lecture method. Gray and Madson (2007) offered 10 ways for teachers to effectively engage students. They included: making regular eye contact; developing a structure for note taking; providing readings to share the lectern; using the pause procedure; and soliciting student responses every two to three minutes. According to Khan (2013), colleges could move in this direction by having fewer or no lecture-based courses, having students do more research and co-ops in the broader world, and employing faculty with broad backgrounds and a sincere desire to guide students.

Gibbons and Shoffner (2004) advocated that school and career counselors should make use of the Social Cognitive Career Theory to assist first-generation students in earning a diploma. This theory focuses on self-efficacy, outcome expectations, barriers, and goals which can help with career and academic decision-making. First-generation students have unique needs that must be addressed by school counselors to succeed with the challenging demands of higher education.

The use of visual images in the college classroom is often effective to meet teaching and learning goals and develop student capacities and skills. Visual images may include graphs, photographs, videos, maps, and visual models. Instructors are urged to support students in attaining visual literacy. The creation and analysis of visual images provides a rich setting for the understanding of tool use and for the development of complex and abstract ideas (Thomas, Place, \& Hillyard, 2008).

As universities attempt to increase graduation rates they must guard against the completion-only paradigm and ensure that quality learning takes place. They must first and foremost chart a course of development and action that leads to excellence for all. This premise in and of itself will lead to a significant increase in the number of students who graduate on time and who are well prepared for the challenges that they will face in their careers and in life (Humphreys, 2012).

\section{Purpose}

The purpose of this study was to conduct a thorough review of the literature in order to present a clear picture of high school and college graduation rates in America and the major variables that impact the rates. The ultimate objective was to establish tenets that might be implemented to enhance the number of competent college graduates. Particular emphasis was placed on demographics for African Americans and what interventions might make them more successful in school and ultimately, enable them to graduate. Further, a presentation was given on a particular HBCU's efforts to graduate its students with implications of alignment with findings from the literature.

\section{Method}

Two major library and information resource data bases were consulted in identifying literature to support this study: Academic Search Premier and ERIC. Topics and subtopics searched in the data bases ranged from “college graduation rates" to "excellent colleges" as related to students in general, and African American students in particular.

Particular attention was given to tenets and findings in the literature that would lead to the formulation of a framework for enhancing graduation rates for college students. Such tenets are presented in tabular form for easy review and examination. To make the study a very practical one, available literature (The college catalog, 
University web site, magazine articles, etc.) on principal resources and approaches to help students succeed at a sizeable, reputable HBCU was examined and illustrated. In light of the more expansive literature review, implications were advanced to denote strong versus not so strong practices employed at the particular HBCU.

\section{Findings}

Findings from a thorough review of literature on graduation issues and concerns were used to support development of a framework of tenets to increase college graduation rates, particularly for African Americans. Further, highlights of specific efforts of a particular HBCU to enhance its graduation rates were reported with implications for future directions.

\section{A Framework of Tenets to Enhance Graduation Rates}

Key findings from the review of the literature were extracted to formulate a framework of tenets to increase college graduation rates for students, African Americans in particular. A major source for this purpose was information from "best colleges". Washington Monthly gave examples of colleges able to graduate the most difficult students to get across the finish line, at a relatively low average net price (Fishman \& Kelchen, 2012). The list included research universities (San Diego State University, Rutgers University-Newark), master's colleges (California State-Fresno, City University of New York-Staten Island), baccalaureate colleges (Elizabeth City State University, College of the Ozarks), and liberal arts colleges (Berea College, KY; Granite State College, NH). Table 1 contains things that they reportedly did to get students across the stage.

A construction of crucial role-playing tenets was formulated from some of the best practices of universities provided in the Washington Monthly report and other related literature on graduation completion. The three overarching role-playing categories were university perspective, faculty/teaching perspective, and individual student perspective. The principal tenets with promise for increasing college graduation rates are provided in Table 2.

It is clear that graduation is a shared concern between the university at large, the faculty, and students. The graduation rates will increase when each party responsibly executes their respective roles and responsibilities.

Table 1

What America's Best Colleges Do to Ensure High Graduation Rates

\begin{tabular}{|l|}
\hline Research Institutions \\
\hline -Have affordable-relatively affordable tuition rates \\
\hline -Make actual graduation rate exceed predicted graduation rate \\
\hline -Rank high for bachelor's degrees conferred on ethnic minorities \\
\hline -Make concerted effort at collecting and analyzing data about its students \\
\hline -Identify roadblocks and develop interventions to improve outcomes \\
\hline -Intervene with such things as mandatory orientation, special programs, retention/success office, and school partnerships \\
\hline -Provide outreach and support to students from disadvantaged backgrounds \\
\hline Master's Colleges \\
\hline -Gather, report on, and use evidence to improve student learning \\
\hline -See where students fall through the cracks \\
\hline -Reach out to every student between their second and third years to provide support \\
\hline -Offer programs to enrich students' academic lives and provide incentives for them to stay invested in finishing \\
\hline -Offer academic support and financial assistance \\
\hline -Offer honors programs for freshmen who pursue their degree full time \\
\hline -Provide incentives to study abroad and do in-depth research \\
\hline
\end{tabular}


(Table 1 continued)

Baccalaureate Colleges

-Provide student-centered environment that enhances learning

-Provide academic initiatives (e.g., summer school program to help the underprepared)

-Offer programs such as MODEL Scholars, GEAR-UP, Upward Bound, and TRiO

-Provide full-time students work instead of paying tuition (Christian school)

-Expect students to complete their program in eight semesters

Liberal Arts Colleges

-Provide educational opportunities to students who have great promise but limited economic resources

-Provide students with four-year scholarships

-Provide student work to cover the cost of books and food

-Lead in delivering online higher education

-Serve as the system's college for adults

-Offer flexible degree programs in high-demand fields and credit for prior learning

-Offer intensive classes to help accelerate path to a degree

Table 2

Tenets for the University, Faculty, and Students to Increase Graduation Rates

University perspective:

-Provide adequate fiscal and personnel resources — these are fundamental in retaining and graduating students (Snyder, 2013)

-Gather and use appropriate student data-identify and rescue potential dropouts (Aarons \& Sawchuk, 2010)

-Close the divide between students' expectations for college-a means to employment

first and a good intellectual experience second; and what universities believe their value is-the inverse (Khan, 2013)

-Reach out to minority students - they face many conditions associated with low graduation rates (Gibbons \& Shoffner, 2004)

-Enhance HBCUs' capacity to educate students-they constitute only three percent of American colleges but graduate 24 percent of all black college students (Cole, 2007)

-Provide counselors capable of helping first-generation students through the use of Social Cognitive Career Theory-it can help with career and academic decision-making (Gibbons \& Shoffner, 2004)

-Do not endorse a completion-only agenda-always make quality learning first (Humphreys, 2012)

Faculty/Teaching perspective:

-Individualize peer and faculty contact and interactions (Oseguera \& Rhee, 2009)

-Use interactive teaching approaches rather than lecture-students reportedly will learn twice as much (Gray \& Madson, 2007)

-Use visual images in the classroom-they can help to meet teaching and learning goals and promote student capacities and skills (Thomas, Place, \& Hillyard, 2008)

-Involve students in research and co-ops in the broader world; and have more faculty with broad backgrounds that show a deep desire to mentor students (Khan, 2013)

Individual student perspective:

-Assess your special abilities and talents - there often is a college looking for someone just like you (Charski, 2007)

-Boost enrollment chances-take honor classes/rigorous courses, get involved in extracurricular activities, engage in internships, and believe in yourself (Charski, 2007)

-Become a master of time management and good study habits-those who do are often motivated to get a bachelor's degree (Snyder, 2013)

-Put forth great effort and have a positive disposition —-these are the students who ultimately succeed (Humphreys, 2012)

\section{An HBCU's Efforts to Enhance Graduation Rates}

First, a thorough review was made of the particular university's capacity for graduating students. It was accredited by the Commission on Colleges of the Southern Association of Colleges and Schools to award the bachelor's, masters, education specialist, Doctor of Education, and Doctor of Philosophy degrees (University Research Data) and was designated as a high research activity university. The university claimed to provide a caring, nurturing environment which challenged students to improve themselves and serve others and 
encouraged alumni and friends to help make it great. It enrolled nearly 9,000 students, making it the fourth largest institution of higher learning in the state, and proclaimed to assemble some of the best students in the nation and a world-class faculty and staff (University Internet, 2013).

The university kept current a well-designed college catalog highlighting its programs and services. It had a division of undergraduate studies as a portal for learning and academic success. The division's initiatives included: a first-year experience program; enhanced freshman orientation and welcome week program; a first year common shared experiences program; a first-year assessment program; a first-year advisement center; comprehensive academic support services; and a W.E.B. Du Bois Honors College. The first-year programs offered an enriched curriculum, cultural and educational opportunities, seminars, colloquia, service and community learning activities, and volunteerism. The support services program provided tutorials, learning skills courses and workshops, supplementary instruction, academic services for student athletes and other "at risk” populations, and mentoring. The Honors College offered superior students a program of study at a pace commensurate with their ability and provided for independent reading and research beyond the regular curriculum. There were 24 chapters of national honor societies at the university and honors at graduation for students who excelled in their studies. The division also provided offices of student retention services, transition program, summer intervention/Bridge program, and center for research. The university also had University College which provided an academically focused, student centered, supportive, structured environment for the entire campus with an emphasis on freshmen; one of its goals was to improve graduation rates (University catalog, 2011-13).

The HBCU offered its 43 undergraduate-degree programs through the colleges of business, education and human development, liberal arts, public service, and science, engineering and technology and the school of lifelong learning. The university also offered programs at the master's, educational specialist, and doctoral levels. Though the university provided academic counseling, students were encouraged to assume responsibility for selecting and completing their course of study (University catalog, 2011-13).

The university offered courses and programs on evenings, weekends, and online. The university's e-Center Foundation funded more than 1,150 iPads scholarships for its 2012 freshman class.

The university was the first institution in the state and one of the first in the nation to comprehensively integrate the iPad into the curriculum. Placing this technology directly in the hands of students gave them a mobile platform on which learning could happen inside or outside of the classroom. The iPads were thought to dramatically enhance the student's learning experience while creating a cost savings on purchase of electronic books as compared to the more expensive paperback books (University Internet, 2013).

The initiative was so successful that universities from across the country inquired about the project (Cyberlearning Summit, 2013).

The college had a well-designed web site. Its connectivity included facebook, twitter, YouTube, Flickr, and JSUgo. It provided for application completion, donations, email, P.A.W.S., blackboard, and web directory. Its contents included a newsroom, discover university, academic units, admissions, athletics, campus life, and alumni. The goal was to make the site as useful and user friendly to campus personnel and visitors as possible (University Internet, 2013). Online capabilities included completion of application for admission.

The success of the university in graduating students was reflected in a number of ways. In 2011 it was ranked number nine among the Top 30 national universities by the Washington Monthly. It was cited as an example of a public university committed to helping first-generation students get ahead (INTRODUCTION: A 
DIFFERENT KIND OF COLLEGE RANKING, 2011). Unfortunately, the college did not make the top 30 list in 2012. Institutional data showed that the university's fall 2012 acceptance rate was 31.3\%, average freshman retention rate was $75 \%$, and six-year graduation rate was $42 \%$. However, the data also showed that in 2010-2011 the university awarded 1,501 degrees, compared with 1,463 being awarded in 2009-2010 (Institutional research data, 2014).

Based on the review of literature, this particular university would get high ratings on numerous initiatives for its efforts to enhance graduation of its students. There were many retention and support programs and activities. However, there was room for improvement. For example, most of its media did not carry information about the well-designed web site and it accomplishments with graduation rates. Based on the constructed framework some implications and future directions for the university may include:

- Categorize the many initiatives into university, faculty, and student roles and responsibilities;

- Determine the efficiency and cost effectiveness of the varies initiatives;

- Arrive at a valid list of programs and activities for further implementation;

- Strengthen and adequately support initiatives of greatest promise.

\section{Summary and Implications}

The banner of success for colleges and universities ultimately rests on their ability to provide students a quality education in a timely fashion. Beautiful facilities, modern technology, and highly recognized extramural activities have their place but academic program completion is the hallmark of excellence. The new global society needs an enlightened citizenry that only higher education can prepare. Students pursue college degrees because they know that the modern economy affords few opportunities for a good career without a degree and many seek institutions that are most likely to help them succeed (INTRODUCTION: A DIFFERENT KIND OF COLLEGE RANKING, 2012).

Colleges will undoubtedly retain the goals of producing research to stimulate economic growth, shaping the character of future leaders, and paving the way for a healthier citizenry. But they must also become committed to social mobility by enrolling more minority students and helping them earn degrees. It was purported that these goals, especially the latter one, could more readily be accomplished (1) if college reputations rise and fall based on student learning results; (2) if university presidents get good press from graduating more low-income students; and (3) if striving parents compete for the prestige of getting their children into colleges that emphasize service. The end result would be a more democratic, equitable, and prosperous nation (INTRODUCTION: A DIFFERENT KIND OF COLLEGE RANKING, 2011).

This study provided evidence that the matter of graduation is on the public agenda. Problems and issues associated with graduation rates are being brought to the forefront. More importantly, some universities are putting their best foot forward and making a breakthrough at retaining and graduating students at higher rates. What seems very much needed is a process of quantitatively and qualitatively determining which efforts at enhancing graduation rates produce the best results.

\section{Conclusion}

Aarons, D. I., \& Sawchuk, S. (2010). Data in action. Education Week, 29(34), 6-9.

Charski, M. (2007). A+ options for B students. U.S. News \& World Report, 143(6), 82.

Cole, D. (2007). At the crossroads of history: America's best black colleges. U.S. News \& World Report, 143(12), 60-62.

Dillon, E. (2011). America’s best master's universities and baccalaureate colleges. Washington Monthly, 43(9/10), 60-88. 
Fishman, R., \& Kelchen, R. (2012). America’s best-bang-for-the-buck colleges. Washington Monthly, 44(10), 31-33.

Gibbons, M. M., \& Shoffner, M. F. (2004). Prospective first-generation college students: Meeting their needs through social cognitive career theory. Professional School Counseling, 8(1), 91-97.

Gray, T., \& Madson, L. (2007). Ten easy ways to engage your students. College Teaching, 55(2), 83-87.

Hoover, E. (2005). College students graduating in the spring of 2006 will enter a steadily improving job market. Chronicle of Higher Education, 52(15), A33.

Humphreys, D. (2012). What's wrong with the completion-agenda-And what we can do about it. Liberal Education, 98(1), 8-17. Introduction: A different kind of college ranking. (2011). Washington Monthly, 43(9/10, 17-20.

Introduction: A different kind of college ranking. (2012). Washington Monthly, 44(9/10), 27-30.

Khan, S. (2013). What college could be like: Imagining an optimized education model. Communications of the ACM, 56(1), 41-43.

Martin, M. A., \& Dahmen, J. (2009). College success among students graduating from public and private high schools. Journal of School Choice, 3, 307-312.

Monto, M. A., \& Dahmen, J. (2009). College success among students graduating from public and private high schools. Journal of School Choice, 3, 307-312.

Mulrine, A. (2010). Getting kids set for college: Obama wants students to not only make it to campus but to graduate too. U.S. News \& World Report, 30-33.

Nemko, M. (2008). Easy ways to improve a college’s retention rate. Chronicle of Higher Education, 54(43), A30.

Oseguera, L., \& Rhee, B. S. (2009). The influence of institutional retention climates on student persistence to degree completion: A multilevel approach. Research in Higher Education, 50, 546-569.

Paskus, L. (2011). Retention strategies rely upon tradition, innovation. Tribal College Journal, 22(4), 8-9.

Rothman, R. (2012). A common core of readiness. Educational Leadership, 69(7), 10-15.

Sibulkin, A. E., \& Butler, J. S. (2005). Differences in graduation rates between young Black and White college students: Effect of entry into parenthood and Historically Black Universities. Research in Higher Education, 46(3), 327-348.

Snyder, T. J. (2013). Part of the solution: Adult students need higher education that works. Presidency, 1-4.

Swanson, C. B., \& Lloyd, S. C. (2013). Graduation rate approaching milestone. Education Week, 32(34), 22.

Thomas, E., Place, N., \& Hillyard, C. (2008). Students and teachers learning to see: Part 1: Using visual images in the college classroom to promote students’ capacities and skills. College Teaching, 56(1), 23-27.

Townes, G. (2007). More African-Americans going to college; fewer graduating. The New York Amsterdam News, 98(48), 33.

Zehr, M. A. (2010). Coaching for success. Education Week, 29(34), 16-18. 